\title{
Entre o conflito e o fracasso: roman pur e ambivalência na obra de André Gide segundo Walter Benjamin
}

Carla Damião

UFG

Resumo: Temos em vista nesse artigo expor a fonte de discussão enunciada na resenha "Crise do romance" de Walter Benjamin no contexto literário francês. Benjamin contrapõe a teoria da obra épica de Alfred Döblin à teoria do roman pur do escritor francês André Gide. Nosso objetivo é aprofundar, neste artigo, o segundo significado, em seu contexto cultural e literário, bem como em sua inserção no romance Os moedeiros falsos, em contraste com outros escritos de Gide.

Palavras-chave: Romance. Ideal e real. Roman pur. Demoníaco.

\section{$O$ romance: a falsa moeda da realidade}

Na resenha intitulada "Crise do romance", Benjamin discute o tema com base na obra e teoria de Alfred Döblin, respectivamente Berlin Alexanderplatz e "A construção da obra épica". Como contraponto a perspectiva döbliniana, Benjamin cita a teoria do roman pur do escritor francês André Gide.

O tema sobre a "crise do romance" na França ${ }^{1}$ ocorre de maneira diferente do debate na Alemanha. O que lá está em questão não é o fim do gênero junto ao "renascimento" da narrativa épica, como o que ocorria na Alemanha. Discute-se, sobretudo, a "decadência" do romance naturalista - a maior expressão do gênero do século XIX - e o surgimento de um novo tipo de romance. O "ocaso" do romance naturalista é, portanto, o motor da "crise" na França, a partir do que se discutem novos valores, regras de composição e escrita. A partir do final do século XIX, até o período entre as duas grandes guerras, esse foi um tema privilegiado nos debates literários. Nesse percurso, segundo diz Raimond, ${ }^{2}$ há o surgimento progressivo de uma multiplicidade de opiniões em grande parte desfavoráveis ao gênero. Da mesma maneira que se questionava o "valor" do romance, perguntava-se em que exatamente ele consistia. As definições gerais, encontradas em dicionários e manuais, deixam de ser aceitas e também o "mapeamento" que efetuava subdivisões do romance histórico, 
social, de costume, psicológico, etc, que prevalecia antes da I Grande Guerra, tornavase superficial. Ao mesmo tempo, a "crise" conferia maior "liberdade" ao romance, afastando-se das definições tradicionais, procurava-se fixar-lhe novos limites, distinguindo quais seriam seus elementos específicos.

Nesse contexto surge a teoria do "roman pur" de André Gide, em seu único romance: Os Moedeiros Falsos. ${ }^{3}$ A “teoria" é exposta por Édouard, personagem principal. Édouard é escritor e anota, numa espécie de "diário" ou caderno, observações sobre o romance que pretende escrever, visto, não por meio da trama e dos personagens, mas, sobretudo, em seus princípios geradores. Algumas páginas de seu caderno de anotações refletem essas preocupações, também manifestas num importante diálogo com outros personagens do livro. Trata-se, portanto, da teoria do "romance ideal" concebida pelo personagem-escritor no romance de Gide, ${ }^{4}$ ou seja, a "ideia do romance no romance do romance". A coincidência entre a teoria de Édouard e a de Gide - como Benjamin faz supor em sua resenha -, apesar de semelhanças quase evidentes, pode ser também vista como argúcia de Gide em, ora se confundir com o personagem e, ora desaparecer por detrás dele, expondo-o ${ }^{5}$ mais do que a si mesmo.

No diálogo entre os personagens (Bernard, Laura, Mme Sophroniska), Édouard é indagado a respeito de seu próximo romance. $O$ que se segue são críticas ao "romancenaturalista", tendo Balzac como principal alvo. ${ }^{6}$ Édouard afirma que o romance é, entre todos os gêneros literários, o mais livre de regras - "lawless", e essa liberdade constrangeria os autores que, com receio, apegar-se-iam à realidade. Suas opiniões, ditas em tom inflamado e buscando atrair indiretamente a atenção de Bernard, são ironizadas por Mme Sophroniska e Laura. Esse "clima" chega a ser até mais interessante do que a teoria que Édouard expõe de maneira "quixotesca"; e, ao mesmo tempo, mostra alguns pontos de vista discordantes da época, demonstra como as opiniões sobre o gênero eram difundidas: ou se fazia um "romance de ideias" ou aquele aderido à realidade: o "naturalista". Esses extremos representam o grande paradoxo na discussão no livro e na discussão em geral. Édouard gostaria de "fazer entrar tudo no romance", mas as idéias lhe são mais importantes. ${ }^{7}$ Ele não convence as duas senhoras, nem a quem quer impressionar, Bernard. Este, ao contrário, ressalta o paradoxo quando, ao apresentar a "moeda falsa", que havia recebido e pretendia dar a Édouard (já sabendo 
o título de seu livro: o mesmo de Gide), recusa entregar-lhe, afirmando que ele não se interessava mesmo pela realidade. A realidade "interessa sim", diz Édouard, "mas me perturba." ${ }^{\prime}$ A dualidade entre ideal e real, apresenta-se mais claramente nesses dois personagens que, ao longo da história, vão se tornando inconciliáveis. A certa altura, Édouard diz: "Bernard é um realista. Receio não poder me entender com ele." A oposição entre os dois espelha a dualidade entre ideal e realidade que vai se tornando também incompatível com a concepção de romance puro. A aproximação de Bernard e Édouard ocorre aos poucos: ele se torna secretário de Édouard, ocupando o lugar de Olivier (sobrinho predileto de Édouard e amigo de Bernard. Olivier gosta de ambos e fica enciumado de sua proximidade - compondo uma triangulação amorosa homossexual), através de uma indiscrição perdoada por Édouard. ${ }^{10}$

Esse personagem, ao mesmo tempo, benemérito e com laivos "demoníacos", 11 demonstra ser, de fato e em alguns casos, um duplo do autor: Um "jovem" Gide simbolista, por um lado, e por outro, um Gide sempre polêmico. O sinal de Édouard que mais faz transparecer o simbolismo, ${ }^{12}$ relaciona-se à própria idéia de "pureza", no caso, do romance. Mallarmé falava do "esforço intelectual" necessário para se alcançar a "poesia pura”. Paul Valéry, em sua obra "A poesia pura", comenta o fascínio dos poetas pela música, cuja freqüência em concertos fazia com que quisessem despertar na poesia as mesmas sensações da música. Não por acaso, Édouard, na mesma conversa com os outros personagens, diz querer realizar em seu romance a "Arte da Fuga" - fazer em literatura o que Bach fez na música. ${ }^{13}$ Gide veste seu personagem com argumentos “antigos”, já que em sua autobiografia, Se o grão não morre (Si le grain ne meurt) escrita ao mesmo tempo que os Moedeiros falsos -, comenta seu afastamento dos "simbolistas." Após narrar as reuniões em casa de Mallarmé, revela sua discordância (num parágrafo que interrompe a cronologia do relato), ao julgar o erro de se "voltar as costas à realidade." "O movimento, dizia, esboçava uma reação contra o realismo, com um redemoinho subsidiário contra o Parnaso. Apoiado em Schopenhauer, ao qual eu não compreendia que alguns pudessem preferir Hegel, ${ }^{14}$ eu tinha por 'contingência' (era palavra de que nos servíamos) tudo que não fosse 'absoluto', toda a prismática diversidade da vida." 15 
A própria maneira como Édouard, ao mesmo tempo inseguro e arrogante, expõe a teoria do roman pur, diante da ironia e ceticismo de seus interlocutores, demonstraria mais certamente uma atitude "crítica" e "autocrítica" 16 de Gide, na medida em que se confunde com o personagem. Em seu Journal des Faux-monnayeurs, ${ }^{17}$ ele diz que gostaria de "colocar tudo na boca de Édouard" (Je crois qu'il faut mettre tout cela dans la bouche d'Édouard), instigá-lo a produzir um roman pur, sabendo, contudo, que ele jamais viria a escrevê-lo. Seu personagem é previamente um "amador", um "fracassado" ("c'est un amateur, um ratê"). ${ }^{18}$ A fórmula ideal e inalcançável do romance em sua "pureza" pode ser remetida ao "romantismo"; a crítica de Gide indica também, nesse caso, a "fraqueza" do personagem. Une-se a ela a própria autocrítica de Édouard que, em seu romance (do romance) faria o seu personagem-romancista voltar à realidade cada vez que ela quisesse fugir. Benjamin diz, em outro texto que resultou de sua entrevista com Gide de 1929, que esse seria o tema principal: "a luta entre os fatos propostos pela realidade e a realidade ideal." 19 Considera Os Moedeiros Falsos como sendo uma "correção criativa da forma do romance usual que emprega o espírito de reflexão filosófica romântica.",20

O debate em torno à "crise do romance", como dissemos, já ocorria na efervescência que caracterizava o meio literário francês. Gide talvez quisesse, com sua teoria, "polemizar" mais o debate e não propô-la convictamente. Essas considerações iniciais são importantes por problematizarem um pouco daquilo que Benjamin faz coincidir na resenha: a "teoria" de Édouard e a de Gide. A teoria, nesse caso, poderia ser, como já dissemos, uma astúcia, cujo intuito seria o de denunciar a escrita do romance como um falseamento - uma "moeda falsa" - do real e se limitar a esse papel crítico, já que a fronteira entre "os fatos da realidade e a realidade ideal" dificilmente poderia ser transposta. Döblin, quem, ao contrário, parece crer no ideal de sua “construção da obra épica", expõe detalhadamente o seu processo e realização. Esse não é o caso de Gide. Ele, bem como os "renovadores" do romance francês, quer suplantar o naturalismo. Não se fala em recuperar a narrativa épica ou romper com o gênero enquanto tal. Os novos recursos técnicos da fotografia e do cinema, ou ainda a montagem como estilo, nesse caso, servem como um auxílio contingente para liberar o romance das "descrições" naturalistas e dos "diálogos referidos". 
A questão da técnica talvez seja a que melhor possa esclarecer a "oposição" que Benjamin faz na resenha. Na teoria do roman pur idealizado por Édouard, deveriase "desprovir o romance de todos os elementos alheios ao gênero." Isso implicava em eliminar aquilo que os novos meios técnicos por si só já podiam exprimir. Assim como a fotografia havia libertado a pintura da exatidão dos detalhes, o fonógrafo deveria cuidar dos "diálogos referidos" e o cinema da necessidade de "descrever", deixando o romance livre para ser a "essência do ser". Importava mais ao roman pur distinguir as variações sutis do comportamento de seus personagens do que descrever a cor de seus olhos. Gide não desconhecia a utilização da montagem como recurso literário (o seu romance foi publicado em 1921, em Paris), mas quando fala da técnica, trata-a como recurso contingente ao romance. Gide faria, portanto, uma utilização "negativa" da técnica, por não admiti-la no interior da obra, mas como auxílio externo a ela.

A "pureza" do romance, por ser ideal, manterá sempre o aspecto de "contradição" por distanciar-se da realidade factual. O roman pur é, portanto, irrealizável, não por falta de coragem de Édouard, mas por não conseguir conciliar realidade ideal e fatos reais. Como pode Benjamin, então, afirmar que a teoria de Gide é "realizada na prática"? O romance Os Moedeiros Falsos foi composto por procedimentos engenhosos, ${ }^{21}$ aos quais, Benjamin, em sua resenha, opõe a narrativa simples e linear. Mas eles são distintos daqueles que Édouard quer propor e que são irrealizáveis. Gide, entretanto, procura evitar as descrições e as intervenções do autor, lidando com uma multiplicidade de pontos de vista, tornando ainda mais complexa e infinita a relação entre autor e personagem, e entre a personagem da personagem (no romance de Édouard a personagem central é um escritor que pensa em como realizar seu romance).

Talvez fosse dessa interiorização absoluta da escrita do autor, que remete à escrita da personagem e a da personagem à de sua própria personagem, que Benjamin caracterizaria o romance escritural puro - que não conhece a "dimensão exterior." Esse "encerramento" infinito do romance em si mesmo, opor-se-ia à obra de Döblin que deixa entrar documentos e fatos da realidade. Gide vive o descompasso entre fazer entrar no romance os fatos da realidade e perder-se no infinito de sua trama, na "gratuidade" dos atos de seus personagens, na multiplicidade dos pontos de vista. Uma 
história que é levada pelo trânsito de personagens, ${ }^{22}$ que surgem associados uns aos outros e que ao final deveria conter a "senha": "poderia continuar".

Na resenha "Crise do romance", Benjamin afirma que "Gide defende as posições de Flaubert, talvez pela última vez. ${ }^{, 23}$ De fato, como comenta Thibaudet, ${ }^{24}$ Gide teria sido leitor assíduo de Flaubert e reconheceria nele algumas influências. Não vamos aprofundar essa questão, embora possamos reconhecer, ao menos, uma grande diferença entre os dois. Gide além de querer negar a "descrição" naturalista, rejeita também a ideia de "impessoalidade" - outro pressuposto básico do naturalismo e realismo. Flaubert certamente apoiou-se em fatos e documentos reais para escrever, por exemplo, Madame Bovary. Mas, quando indagado sobre a pessoa real em que havia se baseado para a concepção do personagem, tornou célebre sua resposta: "Emma Bovary c'est moi”. Segundo interpreta Otto M. Carpeaux, ${ }^{25}$ Flaubert queria que entendessem que o grande protagonista do romance era a "estupidez humana em província." Gide, bem ao contrário, diz em seu Journal des faux-monnayeurs, ${ }^{26}$ que quer evitar a narração impessoal. De fato, a maioria de seus personagens é de alguma forma identificável na vida real, ${ }^{27}$ além de sua propositada exposição pessoal através da publicação dos Diários e da autobiografia Se o grão não morre.

A posição "conservadora" de Gide, ao "defender" as ideias de Flaubert, deve ser relativizada, se tivermos em vista o interesse que Benjamin tem pelo escritor francês e que são explícitos em outros textos seus. ${ }^{28}$

\section{O diário de páginas opostas de Bernard}

Em os Subterrâneos do Vaticano, o personagem bastardo de Gide, Lafcadio, viaja no trem onde comete o assassinato de Fleurissoire, fruto de uma action gratuite. Gide publica o livro na ante-véspera da Primeira Guerra, fermentando o explosivo movimento da juventude européia que resultou nos movimentos de vanguarda como o expressionismo, dadaísmo e surrealismo. Para Benjamin, Lafcadio "encontrou nos surrealistas seus alunos mais inteligentes" 29 (repete Leon Pierre-Quint). Gide é, a propósito, o único autor entre os da geração anterior aos surrealistas, a ser citado na primeira revista do movimento (Revue Littérature), segundo Benjamin. ${ }^{30}$ Essa 
reverência dos jovens surrealistas encontra uma reciprocidade na atenção de Gide às crianças e aos adolescentes. Na narrativa de sua própria infância, Gide fala da importância de seu tio Charles, ${ }^{31}$ de como este o impressionava e de como ele o queria impressionar. A figura do "tio" está presente, por exemplo, nos Moedeiros falsos através de Édouard, em meio a adolescentes (Olivier, Bernard, Vincent e Sarah) e crianças (Boris, Bronja, etc.). ${ }^{32}$ Inclui-se nesse interesse por personagens adolescentes, o tema da homossexualidade, o que se nota, principalmente, através de um dos triângulos amorosos do romance Os Moedeiros falsos, composto por Édouard, Olivier e Bernard. A educação, nesse caso, não ocorre necessariamente do mais velho para o mais novo. Ao contrário, o mais velho parece ser mais frágil e o mais novo, impulsionado a buscar sua liberdade. É o tema, já presente, na parábola de "A volta do filho pródigo.” Os diálogos principais desse livro de Gide são extensamente citados por Benjamin em seu programa radiofônico em comemoração ao aniversário de Gide: Gides Berufung (A vocação de Gide). ${ }^{33} \mathrm{Na}$ versão do filho pródigo contada por Gide, o filho mais velho que retorna e é perdoado pelos pais, mantém um diálogo com o irmão mais novo - este, cheio de admiração pelo irmão, impetuoso e resoluto em também partir -, ouve do irmão mais velho suas dificuldades como um fracassado. Em Os Moedeiros Falsos, o mais velho, Édouard, é visto como um fracassado pelo próprio Gide; mas, ao mesmo tempo, é admirado pelo sobrinho Olivier. Teria o personagem Bernard, uma correspondência com o filho pródigo que parte no início do livro e fracassa no final? É o que sugere o final do livro: como um recomeço da parábola do filho pródigo, lemos na última frase de Édouard: "Estou bastante curioso para conhecer Caloub". Caloub é o irmão caçula de Bernard.

O "demoníaco" tem a função de impelir a fuga, de mover o jovem em busca da liberdade. "O diabo, diz Benjamin, ${ }^{34}$ avança [...] com a voz do anjo da missão." Ele não surge como o "tentador da carne", mas como o "príncipe da tristeza" que segreda ao personagem "três grandes promessas enganosas: a liberdade sem limite, a profundeza sem limite, a espiritualidade sem limite." ${ }^{35}$ Nos Moedeiros falsos "o diabo anda incógnito", mas Gide o anuncia, desde o início, quando diz sobre Bernard (que então se preparava para os exames escolares): "A família respeitava sua solidão, mas o demônio não." ${ }^{36}$ Quando Bernard, depois de sua fuga, usa o talão de depósito de bagagem que 
Édouard deixara cair, para roubar-lhe a mala no guarda volumes e o funcionário lhe pede para pagar o depósito, Gide denuncia novamente a presença demoníaca. ${ }^{37}$ Essa também se anuncia no discurso "racional" de Vincent (irmão mais velho de Olivier), cuja "cultura positiva" impedindo-o de acreditar no "sobrenatural", "dava ao demônio grande vantagem." Em “Conversa com André Gide” ("Gespräch mit André Gide”), Benjamin fala da atenção que Gide dá à psicologia que, ao contrário do drama que estabelece papéis definidos (amor, ódio, coragem), em si completos, descobre "ódio no amor; e na coragem, a covardia." 38

O "aprendizado" de Bernard não ocorria através da tutoria do tio Édouard, ao tornar-se seu secretário particular. Ele tem exames a enfrentar: esse é o início do livro que se une a uma das tensões principais, expressa na passagem, citada por Benjamin, ${ }^{39}$ de "Bernard e o Anjo.",

Bernard aprendeu através de oposições. Querendo demonstrar maturidade, diz a Laura: "Há alguns dias, tenho um caderno como Édouard. Na página da direita escrevo uma opinião, desde que na página esquerda, bem em frente, possa escrever a opinião contrária." ${ }^{41}$ Esses extremos refletem o ato de inquietação por uma única escolha. Nos Frutos da terra, Ménalque diz: "A necessidade da opção sempre me foi intolerável; escolher não era bem eleger o que me afigurava, e sim rechaçar o que não elegia." ${ }^{42} \mathrm{O}$ movimento oscilante dos personagens de Gide caracteriza, para Benjamin, uma "evidência dialética." Em "Gespräch mit André Gide”, Benjamin cita Gide, ao dizer: "Em cada direção que comecei uma vez fui até o extremo, para poder depois, com igual decisão, voltar-me à direção contrária"43 - ao que comenta: "Esta negação fundamental do centro dourado, esta confissão em favor dos extremos, que outra coisa é senão dialética, não como método de um intelecto, mas como alento vital e como paixão deste homem?"

A pedagogia de Gide consiste em mostrar mais as ambigüidades do que o "reto caminho" ou o "centro dourado." Giram em torno desse ensinamento, o tema da dificuldade da escolha em função do abandono de possibilidades, a humildade (a volta do filho pródigo) e a liberdade (o filho mais novo que se vai). A história de "Bernard e o anjo" demonstra a manutenção do conflito - "eles passaram a noite lutando", não houve um vencedor: "o anjo se retirou sem que nenhum dos dois fosse vencedor." 
contrária de Bernard levou-o a se revoltar contra sua própria revolta; a "indecisa" de Ménalque, ao erro.

A "dialética apaixonada" de Gide, analogamente à dialética de Benjamin, é representada pela ambiguidade. $O$ seu movimento pode resultar no negativo - na "desmontagem" da vida do personagem. Contudo, parece-nos que Benjamin procura enfatizar a "tensão dos extremos", a luta dos opostos. A ênfase é voltada para a "tensão" que caracteriza a dualidade, como um jogo entre forças contrárias. Em Gide, a tensão tende a ser encerrada quase sempre na negatividade: a ascensão de um personagem de uma obra, por exemplo A porta estreita, é prejudicada pelo fracasso. Esta obra marcada por um ascetismo religioso é contraposta em seguida ao Imoralista, no qual Gide questiona os limites morais. Seu personagem central, Michel, também fracassa. Anthime, personagem dos Subterrâneos do Vaticano, reúne esses dois personagens ao criticar os valores morais e religiosos e converter-se posteriormente ao catolicismo: ele "fracassa" em seu ateísmo e não ascende espiritualmente. O que parece importar mais a Gide, é demonstrar a situação de conflito, indicar a necessidade de uma escolha, e esta se realizada já contem em si a indicação do fracasso, por excluir outras possibilidades.

Na resenha "Crise do romance", tanto com relação a Döblin quanto em relação a Gide, Benjamin parece ter enxergado aquilo que lhe era próprio, isto é, em seus textos sobre os temas mais variados e, em particular nas resenhas sobre livros, podemos encontrar de maneira desenvolvida ou subjacente, conceitos e teorias que Benjamin desenvolveu nesse tipo de abordagem crítica sobre obras literárias. Ele ressalta, por exemplo, em Döblin, o princípio da montagem - para ele importante, mas pouco comentado por Döblin, sobretudo, em seu texto sobre a construção da obra épica, no qual a montagem nem menos é mencionada. Quanto à teoria do roman pur, citada como foi na resenha, servindo de contraponto à teoria de Döblin, não se pode afirmar um total interesse que permitisse a Benjamin ali expor os detalhes aos quais nos remetemos. Porém, como a aparência era de discordância com a teoria de Döblin, foi necessário demonstrar detalhes da obra citada, Os moedeiros falsos, e outros escritos para verificarmos o alcance da crítica de Benjamin. Importante igualmente é dizer que Benjamin se deteve muito mais na leitura da obra de Gide do que na de Döblin, tecendo comentários, defendendo Gide de seus opositores (da direita e da esquerda), escrevendo 
resenhas e textos, apresentando o programa de rádio em homenagem ao aniversário de Gide, no qual encontramos várias traduções de trechos de sua obra. Podemos sucintamente destacar alguns dos temas desenvolvidos por Benjamin sobre Gide: 1. A questão do fascismo que adota o esteticismo (ideia também desenvolvida no ensaio sobre a obra de arte, no qual Benjamin recupera, ao mesmo tempo, a concepção grega de estética como percepção. Analogamente, ele procura descobrir no esteticismo de Gide, valores helênicos que o salvam da visão utilizada pelo nacionalismo fascista); 2. A questão da pedagogia presente - o papel de grande "educador" da França, na linhagem de Pascal -, uma espécie de "tio" dos surrealistas; e principalmente, 3. a ênfase na dialética de Gide que preferimos chamar de "ambivalência."

Benjamin, ao falar de Gide, evoca várias vezes Oscar Wilde, de fato o grande responsável, junto a Dostoievski, pelo “demonismo" gideano. Poderíamos também lembrar uma história, que de alguma forma se encaixa quando Benjamin, ao falar desses escritores e suas obras, tem em vista seus próprios conceitos. Na história que Wilde contou a Gide, ${ }^{46}$ as flores pediam emprestado ao rio algumas gotas d'água para chorarem a morte de Narciso. O rio responde que ele próprio secaria suas águas se fosse lamentar a perda, porque ele o amava. Claro, diziam as flores, como não amar Narciso, "se ele era tão belo." O rio não sabia de sua beleza, para o espanto das flores, que viam Narciso todo dia inclinar-se sobre sua margem. "Se eu o amava, disse o rio, era porque, quando ele se contemplava em minhas águas eu me via em seus olhos."47 O título dessa pequena fábula era "O discípulo", mas sua "moral" era a de que, na verdade, discípulos não existem, só a semelhança refletida nos olhares. Os conceitos "positivos", por assim dizer, que Benjamin ressalta ao falar de Döblin e Gide, possuiriam, a nosso ver, um pouco dessa semelhança narcísica.

Ressalte-se, contudo, a coragem de Benjamin que, ao "defender" Gide e se interessar por escritores "burgueses" como Proust e Valèry, opõe-se à postura dogmática da intelectualidade de esquerda. Atitude correlata à que teve ao recuperar a representatividade da alegoria e ao enfatizar a utilização da montagem, opondo-se aqui não só à ortodoxia marxista de Lukács, mas também à concepção tradicional de símbolo. 
Abstract: This article aims to display the source of the debate started by Walter Benjamin in his essay "Crisis of the novel", concerning the French literary context. Benjamin opposes Alfred Döblin's theory on the epic to the French writer André Gide's theory of the roman pur. In this article, we aim to deepen the second meaning in its literary and cultural context, as well its insertion in the novel The counterfeiters, contrasting it to other writings by Gide.

Keywords: Novel. Ideal and reality. Roman pur. Demoniac.

\section{Referências Bibliográficas}

ANDRÉ, R. Le Journal d'André Gide. In: Bulletin des Amis d'André Gide, 15, abril-julho, 1987.

ARLAND, M. e MOUTON, J. (Org). Entretiens sur André Gide. Paris: Mouton, 1967.

BENJAMIN, Walter. André Gide und Deutschland. In: Gesammelte Schriften, Vol. IV-1. Frankfurt/M.: Suhrkamp, 1991.

BENJAMIN, Walter. Crise do romance. Trad. de Celeste H. M. de Souza. In: BOLLE, Willi (Org.). Walter Benjamin: Documentos de cultura, documentos de barbárie. São Paulo, Cultrix/Edusp, 1986.

BENJAMIN, Walter. Gesammelte Schriften, Vol. I-VII. Editado por R. Tiedemann e H. Schweppenhäuser. Frankfurt am Main: Suhrkamp, 1991.

BENJAMIN, Walter. Gespräch mit André Gide. In: BENJAMIN, Walter. Gesammelte Schriften, Vol. IV, 1. Frankfurt/M.: Suhrkamp, 1991.

BENJAMIN, Walter. Gides Berufung. In: Gesammelte Schriften, Vol. VII, 1. Frankfurt/M: Suhrkamp, 1991.

BENJAMIN, Walter. O narrador. In: BENJAMIN, Walter. Obras Escolhidas, Vol. I. Trad. Sérgio Paulo Rouanet. São Paulo, Brasiliense, 1985.

BENJAMIN, Walter. Origem do Drama Barroco Alemão. Tradução de Sérgio Paulo Rouanet. São Paulo, Brasiliense, 1984.

BENJAMIN, Walter. Zum gesellschaftlichem Standort des französischen Schrifstellers. In: BENJAMIN, Walter. Gesammelte Schriften, Vol. II, 2. Frankfurt/M: Suhrkamp, 1991.

BOLLE, Willi. Fisionomia da Metrópole Moderna. Representação da História em Walter Benjamin. São Paulo: Edusp, 1992.

BROSMAN, C.S. An annoted bibliography of criticism on André Gide 1973-1988. New York/London: Garland Publishing, 1990.

CONNER, T. (Org.). André Gide's Politics. Rebellion and Ambivalence. New York: Palgrave, 2000 .

CORDLE, T.R. André Gide. New York: Twayne Publishers, 1993.

DAMIÃO, Carla M. Sobre o declinio da "sinceridade". Filosofia e autobiografia de JeanJacques Rousseau a Walter Benjamin. São Paulo: Loyola, 2006. 
DAMIÃO, Carla M. Sobre o significado de épico na interpretação benjaminiana de Brecht. In: SELIGMANN-SILVA, Márcio. (Org.). Leituras de Walter Benjamin. São Paulo: Annablume, 2007, $2^{a}$ edição, 1999, $1^{a}$ edição.

DÖBLIN, Alfred. Berlin Alexanderplatz. Die Geschichte vom Franz Biberkopf. München: DTV, 1988.

DÖBLIN, Alfred. Berlin Alexanderplatz. Trad. Sara e Teresa Seruya. Lisboa: Dom Quixote, Lisboa, 1992.

DÖBLIN, Alfred. Der Bau des epischen Werks. In: Jahrbuch der Sektion für Dichtkunst. Berlin: Fischer Verlag, 1929.

DU BOS, Charles. L'échec esthétique des Faux-Monnayeurs. In: Les Critiques de notre temps et Gide. Garnier, 1971.

DUGAST-PORTES, Francine. L'adolescence dans Les Faux-Monnayeurs. In: Roman 20-50.

ELLMANN, R. Oscar Wilde. Trad. José Antonio Arantes. São Paulo: Ed. Schwarcz, 1989.

FERNANDEZ, R. Gide. Paris: Corrêa, 1931.

FLAUBERT, Gustave. Madame Bovary. Trad.: Sérgio Duarte. Ediouro, s/d.

FOUCART, C. André Gide dialogue avec la nouvelle génération allemande: la rencontre avec Walter Benjamin en 1928. In: Bulletin des Amis d'André Gide, Vol. VII, n. 44, outubro, 1979.

FRYER, J. André and Oscar. The literary friendship of André Gide and Oscar Wilde. New York: St. Martin's Press, 1998.

GAGNEBIN, Laurent. André Gide nous interroge. Lausanne: Cahiers de La Renaissance Vaudoise, 1961.

GENETTE, G. Figures II. Paris: Seuil, 1976.

GIDE, André. Se o grão não morre. Trad. Hamílcar de Garcia. Rio de Janeiro : Editora Nova Fronteira, 1982.

GIDE, André. Incidences. Paris: Gallimard, 1924.

GIDE, André. Journal. Vol. I/II. Paris: Gallimard, 1951.

GIDE, André. Les Faux-monnayeurs. In: GIDE, André. Romans, Récits et Soties. Paris: Gallimard.

GIDE, André. Os frutos da terra. Trad. Sérgio Milliet. São Paulo: Difusão Européia do Livro, 1961.

GIDE, André. Os moedeiros falsos. Tradução de Celina Portocarrero. Rio de Janeiro, Francisco Alves, 1983.

GIDE, André. Oscar Wild. In memoriam. In : GIDE, André. Oeuvres completes, t. III. 1935.

GIDE, André. Romans, Récits et Soties, Oeuvres lyriques. Paris: Gallimard (Éd. de la Pléiade), 1958.

GIDE, André. Si le grain ne meurt. Paris: Gallimard, 1955.

GOULET, Alain. Édouard le démoniaque. In: Roman 20-50, - Revue d'étude du roman du XXe siécle, Dossier critique: Les faux-monnayers d'André Gide, Lille, n.11, 136p., mai 1991.

GOULET, Alain. Si le Grain ne meurt: La construction du moi par l'autobiographie, Texte 1, 1982. 
HARTUNG, R. Das prekäre Gleichgewicht: André Gide, Tagebuch 1939-1949, In: Kritische Dialogue. Frankfurt: S. Fischer, 1973.

LUCEY, M. Gide's Bent. Sexuality, Politics, Writing. Oxford: Oxford Press, 1995.

MANN, K. André Gide und die Krise des modernen Denkens. Hamburg: Rowohlt Taschenbuch, 1984.

MANN, K. André Gides Journal 1889-1939. In: Das innere Vaterland: Literarische Essays aus dem Exil. Munique: Spangenberg im Ellerman, 1986.

MARTY, E. L'apologie de l'influence: La Citation dans le Journal d'André Gide. In: Revue des Sciences Humaines. Vol. 196, 1984.

MARTY, E. L’Écriture du jour: Le “Journal” d'André Gide. Paris: Seuil, 1985.

CARPEAUX, Otto Maria. Introdução a Mme Bovary. In: FLAUBERT, Gustave. Madame Bovary. Ediouro, s/d.

PIERRE-QUINT, L. André Gide. As vie, son oeuvre. Paris: Stock, 1933.

RAIMOND, Michel. La Crise du Roman. Des lendemains du Naturalisme aux annéss vingt. Paris: Corti, 1967.

RENARD, Paul. Passavant et Édouard, Cocteau e Gide. In : Roman 20-50 - Revue d'étude du roman du XXe siécle, Dossier critique: Les faux-monnayers d'André Gide, Lille, n.11, 136p., mai 1991.

THIBAUDET, Albert. Roman pur et pure critique. In: Les Critiques de notre temps et Gide. Garnier, 1971.

VIART, Marie - Hélène. Hasard et Necessité. In: Roman 20-50, nº 11, maio 1991.

\section{Notas}

${ }^{1}$ Cf. RAIMOND, La Crise du Roman. Des lendemains du Naturaliste aux annéss vingt.

${ }^{2}$ RAIMOND, La Crise du Roman. Des lendemains du Naturaliste aux annéss vingt.

${ }^{3}$ GIDE. Les Faux-monnayeurs. Utilizamos a tradução de Celina Portocarrero de 1983, Ed. Francisco Alves, RJ. O romance foi publicado pela primeira vez em 1926.

${ }^{4}$ Esse recurso é utilizado por Gide em ouros escritos: Em Les Cahiers d'André Walter, Walter é um escritor e sua obra chama-se Allain. Na sátira Paludes, escrito em 1895, há o personagem do escritor que escreve Paludes, com semelhantes anotações em diário, debates literários (onde o escritor dizia que escrevia Paludes, ao mesmo tempo, Gide faz um retrato irônico do meio literário da época) e trechos da história.

${ }^{5}$ DU BOS. L'échec esthétique des Faux-Monnayeurs, p. 52, comenta a relativa imparcialidade de Gide em função de Édouard. "Se a teoria do romance puro representa a última astúcia de Édouard, a astúcia derradeira de Gide reside na liberdade dele em se reservar diante da própria teoria. [Si la théorie du roman pur représente la ruse dernière d'Édouard, la ruse dernière de Gide reside dans la liberté qu'il entend se réserver vis-à-vis de cette théorie même.]" (Tradução nossa). 
${ }^{6}$ Balzac, segundo argumenta Édouard, pertenceu à época de expansão do romance, mas jamais teria pretendido codificar o gênero. Contudo, a partir de sua obra decretam que era próprio ao romance fazer "concorrência com o registro civil": "Concorrência ao estado civil! Como já não existisse suficiente feiúra no mundo! O que tenho eu a ver com o estado civil! O estado sou eu, o artista. Civil ou não, minha obra pretende não fazer nenhuma concorrência" (GIDE. Os moedeiros falsos, p. 165).

${ }^{7}$ GIDE. Os moedeiros falsos, p. 166 e 168.

${ }^{8}$ GIDE. Os moedeiros falsos, p. 171.

${ }^{9}$ GIDE. Os moedeiros falsos, p. 182.

${ }^{10}$ Tal qual do Imoralista (onde há o roubo de uma tesoura com a qual Michel, o personagem principal, compactua em silêncio - GIDE. Romans, Récits et Soties, Oeuvres lyriques, p. 403) Gide deixa ocorrer pequenos furtos e atitudes como a de Bernard que leu o "diário" de Édouard - recurso através do qual podemos conhecer detalhes da vida dele sem que Gide "descreva" o seu passado -; fundamentado pelo tema do "ato gratuito" (já presente em Le Prométhée mal enchainé - GIDE. Romans, Récits et Soties, Oeuvres lyriques, p. 305 - , no qual se lê: "Uma ação gratuita! À vós, que a isto nada dizem. Isso para mim parece extraordinário. Penso há muito tempo que isto é o que distingue os homens dos animais: uma ação gratuita. Eu chamo homem: o homem capaz de uma ação gratuita. [Une action gratuite! Ça NE vous dit rien, à vous. Moi ça me paraît extraordinaire. J'ai longtemps pense que c'était là CE qui distinguait l'homme des animaux: une action gratuite. J'appelais l'homme: l'homme capable d'une action gratuite.]" (Tradução nossa). A idéia de "ato gratuito" se traduz em pequenos e grandes crimes em outros escritos: como através do personagem ateu de Os subterrâneos do Vaticano, que se converte ao cristianismo ao final, Anthime Armand-Dubois, o qual, em suas experiências com cobaias, constrange a esposa (ela interrompe sua pesquisa alimentando as cobaias) - GIDE. Romans, Récits et Soties, Oeuvres lyriques, p. 689; ou quando no conhecido episódio da mesma obra, Lafcadio, o personagem bastardo (tema presente também nos Moedeiros Falsos), sem motivo algum mata uma pessoa, atirando-a de um vagão de um trem. Benjamin se refere a essa passagem, transcrevendo parte dela em „Zum gesellschaftlichem Standort des französischen Schrifstellers.“

${ }^{11}$ Cf. GOULET. Édouard le démoniaque: GIDE. Les Faux-Monnayeurs, p. 5 a 18: "A força do diabo possui, em primeiro lugar, a arte da palavra, do convencimento lógico, da justificação, do sofisma, da arte de seduzir [...] No romance, a palavra não é mais divina, ela caminha em direção da moeda falsa, retorcida, irônica, ambígua, crítica [...] Édouard não sabia ser o modelo de homem bom e de bom romancista, em face a um Passavant oportunista, hipócrita e perverso. Ambos são, à sua maneira, falsos moedeiros. [La force du diable tient d'abord à l'art de la parole, du raisonnement, de la justification, du sophisme, à l'art de séduire [...] Dans ce roman, le verbe n'est plus divin, il est passe du côté de la fausse monnaie, retorse, ironique, ambigüe, critique [...] Édouard ne saurait être le modèle de l'homme bon et du bon romancier, em face d'un Passavant opportuniste, hypocrite et pervers. Tous deux sont, à leur manière, de faux-monnayeurs.]" (Tradução nossa).

${ }^{12}$ Os simbolistas vêem em Edgar A. Poe como seu precurssor. Jean Moréas deu nome ao movimento (renunciando posteriormente a este), mas têm-se como o grande "fundador", Baudelaire. O simbolismo engloba nomes como de Paul Verlaine, Rimbaud e Mallarmé. Paul Valèry e Gide são tidos como os últimos simbolistas franceses.

${ }^{13}$ GIDE. Os Moedeiros Falsos, p. 169. 
${ }^{14}$ Segundo Benjamin, em André Gide und Deutschland, p. 501, Gide conta uma anedota de como os simbolistas entraram em contato com a Estética de Hegel: não teria sido via Sorbonne, através de Vitor Cousin, mas via um incidente cômico. Um dos poetas do "círculo" de Mallarmé, teria recebido como "embalagen", na compra de um saquinho de batatas quentes, uma folha da Estética traduzida para o francês.

${ }^{15}$ GIDE. Se o grão não morre, p. 199.

${ }^{16}$ Cf. THIBAUDET. Roman pur et pure critique, p. 54-59.

${ }^{17}$ GIDE. Journal des Faux-monnayeurs, p. 59.

${ }^{18}$ GIDE. Journal des Faux-monnayeurs, p. 59.

${ }^{19}$ BENJAMIN. André Gide und Deutschland, p. 448.

${ }^{20}$ BENJAMIN. André Gide und Deutschland, p. 448.

${ }^{21}$ Sobre técnicas empregadas por Gide, (Cf. VIART, Hasard et Necessité, p. 57), a autora cita outras "teorias do romance" em Gide (em Isabelle e Paludes) que orientam a utilização de pressupostos estilístico literários, como, por exemplo: a "diversidade de pontos de vista", "a renúncia à unidade, à simplicidade e à necessidade diegética" ao que se alia o "culto do instante e da contingência". Idéias que se entrelaçam à crítica de Gide ao "hegelianismo" dos simbolistas.

${ }^{22}$ Ao final da segunda parte Os Moedeiros Falsos (p. 197), Gide diz: "Se ainda me acontecer um dia inventar uma história, não a deixarei ser habitada a não ser por caracteres enérgicos, que a vida longe de embotar, aguce. Laura, Douviers, La Pérouse, Azäis ... O que fazer com toda essa gente. Não os procurei, foi seguindo Bernard e Olivier que os encontrei em meu caminho. Pior para mim; agora, estou preso a eles."

${ }^{23}$ BENJAMIN. Crise do romance, p. 127.

${ }^{24}$ THIBAUDET. Roman pur et pure critique, p. 56-57. Albert Thibaude relaciona o personagem da Éducation Sentimentale, Frédéric Moreau, como um duplo enfraquecimento do autor, ao Édouard de Gide, afirmando que ambos emprestariam muito de si ao personagens, ao mesmo tempo que manteriam uma postura crítica frente a eles no romance. Gide teria tido como "livro de cabeceira" a Correspondance de Flaubert e saberia lidar com a mesma referência.

25 CARPEAUX. Introdução a Mme Bovary. Carpeaux refere-se à frase no tribunal utilizada por Flaubert para se defender das acusações sofridas pela publicação do romance.

${ }^{26}$ GIDE. Journal des faux-monnayeurs, p. 22.

${ }^{27}$ Nos Moedeiros falsos, Paul Renard (Passavant et Édouard, Cocteau e Gide, p. 19 a 30) relaciona o escritor Jean Cocteau ao, também escritor, Passavant no romance. Outros personagens desse romance - Mme Sophroniska, por exemplo, correspondia a uma psicanalista com quem Gide teria feito seis sessões -, tem relações com pessoas reais. Benjamin (in Gides Berufung, p. 265) fala do diálogo no Journal des faux-monnayeurs, "Identification du démon", indicando Oscar Wilde como o interlocutor. Richard Ellman (in Oscar Wilde, p. 311), diz também que Wilde é Ménalque nos frutos da terra. Oscar Wilde, condena o uso da primeira pessoa nos Frutos da Terra, dizendo: "Preste atenção, querido, falta agora o senhor me fazer uma promessa. Os frutos da terra, está bem ... está bem ... Mas, querido, prometa-me: agora não escrever nunca mais eu" [Écoutez, dear, Il faut maintenant que vous me fassiez une promesse. Les Nourritures Terrestres, c'est bien ... c'est bien ... Mais dear, promettez-moi: maintenant n'écrivez plus jamais je] (relatado por Gide, em Oscar Wilde: in memoriam) [Tradução nossa]. 
${ }^{28}$ Cf. DAMIÃO. Sobre o declinio da "sinceridade". Filosofia e autobiografia de Jean-Jacques Rousseau a Walter Benjamin, Capítulo I e Anexos.

${ }^{29}$ BENJAMIN. „Zum Gesellschaftlichen Standort des französischen Schriftstellers“, p. 797. Benjamin repete aqui seu amigo, Léon Pierre-Quint, crítico literário francês e autor de uma biografia sobre Gide (PIERRE-QUINT. André Gide. Sa vie, son ouevre.), cujo anexo tinha como título: "André Gide, ou l'Oncle Dada".

${ }^{30}$ BENJAMIN. Gides Berufung, p. 268.

${ }^{31}$ GIDE. Se o grão não morre.

${ }^{32}$ Cf. DUGAST-PORTES. L'adolescence dans Les Faux-Monnayeurs.

${ }^{33}$ BENJAMIN. Gides Berufung, p. 260 a 264.

${ }^{34}$ BENJAMIN. Gides Berufung, p. 265, com relação ao filho pródigo.

${ }^{35}$ BENJAMIN. Gides Berufung, p. 265.

${ }^{36}$ GIDE. Os Moedeiros falsos, p. 7.

${ }^{37}$ GIDE. Os Moedeiros falsos, p. 73.

${ }^{38}$ BENJAMIN. Gespräch mit André Gide, p. 504. No estudo de Gide sobre Dostoievski, Gide diz "não conhecer um escritor mais rico em contradições e em inconseqüências do que Dostoievski" - "antagonismos", diria Nietzsche. Situa a "duplicidade" de Emma Bovary para diferenciá-la da "dualidade" dos personagens de Dostoievski, nos quais haveria a consciência da dualidade junto a sua simultaneidade. (Diferentemente dos casos patológicos em alguns romances, onde uma personalidade desconhece o seu reverso numa única personagem, alterando-se em momentos diferentes). No herói de Dostoievski confundem-se sentimentos opostos como amor e ódio. Gide se pergunta se essa dualidade existiria de fato ou se é fruto da imaginação do escritor. Cita, à guisa de resposta, o "paradoxo" wildeano, segundo o qual "a natureza imita a arte". Uma inversão a partir da qual enxergaríamos mais a natureza "retratada" nas paisagens de Corot do que ela própria. Tese que Gide aplica ao romance e à psicologia: nós não poderíamos saber como ele é, mas como no-lo dizem ou nos persuadem ser. Dostoievski "abriria os olhos do leitor" para o quadro "patológico" de dupla personalidade, não aquela que é inconsciente de suas versões diferentes, mas fazendo-as agir simultaneamente e de forma consciente em seus personagens.

\section{${ }^{39}$ BENJAMIN. Gides Berufung, p. 268.}

${ }^{40}$ Bernard havia passado nos exames, sentindo enorme alegria (pensava reconciliar-se com o pai). Outro colega seu, também aprovado, estava, ao contrário, triste por ter perdido a mãe. Bernard quis ser simpático com ele, mas não conseguiu. Dirigiu-se então ao jardim de Luxembourg e sentou-se num banco. "Diz-se que há caminhos no mar, mas não estão traçados, e Bernard não sabia qual era o seu" (GIDE. Os moedeiros falsos. p. 209), e refletia quando surgiu um anjo. $\mathrm{O}$ anjo o leva de volta para encontrar o amigo (o arrependimento); levou-o para igreja da Sorbonne (para sentir o amor); depois desapareceu. Quando reapareceu novamente, disse-lhe: "Vai ser preciso tomar uma decisão. Você só viveu a esmo. Deixará que o acaso disponha de você? Você quer servir a alguma coisa. É preciso saber a quê" (GIDE. Os moedeiros falsos. p. 301). Bernard pede a ele que o guie. Eles passam por uma sala onde várias pessoas debatem temas políticos (entre eles, o terceiro orador, enaltecia a França e sua missão de combate). Oferecem uma folha de adesões a Bernard, que pergunta ao anjo se deve assinar: "Se duvida de si mesmo...", diz o anjo. Bernard não assina e volta a ouvir o orador que 
"ensinava o método certo para jamais se enganar, que era o de renunciar para sempre e julgar por si mesmo, mas conforma-se sempre com o julgamento de seus superiores". Bernard, indignado, pergunta quem são esses superiores. Pede então ao anjo que lute, em seu lugar, com o orador. Mas o anjo responde ser com ele que quer lutar, naquela noite. "Os dois lutaram até a aurora. O anjo se retirou sem que nenhum dos dois fosse vencedor" (GIDE. Os moedeiros falsos. p. 303).

${ }^{41}$ GIDE. Os Moedeiros Falsos, p. 174.

${ }^{42}$ GIDE. Os Frutos da terra, p. 47. "O erro (de Ménalque) de minha vida foi desde então o de não continuar nenhum estudo durante muito tempo, por não ter sabido conformar-me com renunciar a muitos outros." Bernard queria ter "livre escolha", mas para agir teria que decidir logo e também por ter "horror à decisão", por isso precipita-se. Édouard escreve em seu diário: "Eu deveria ter desconfiado de um gesto tão excessivo quanto o de Bernard no início da história... O hábito que assumiu, de revolta e oposição, leva-o a se revoltar contra a própria revolta. Certamente não é um de meus heróis que me tenham decepcionado... Talvez ele tenha se deixado levar por si mesmo cedo demais" (GIDE. Os Moedeiros Falsos, p. 175).

${ }^{43}$ BENJAMIN. Gespräch mit André Gide, p. 508.

${ }^{44}$ BENJAMIN. Gespräch mit André Gide, p. 508. Esse trecho é também citado o texto Zum geselschaftlichen standorf des französischen schriftstellen, p. 795, onde Benjamin acrescenta: "O mundo é também completo nos extremos, também saudável e natural. [Die welt ist auch in den Extremen noch ganz, noch gesund, noch natur.]" (Tradução nossa).

${ }^{45}$ GIDE. Os Moedeiros Falsos, p. 303. Essa passagem provavelmente tem relação com "A volta de Jacó para Canaan" - capítulo 32 do Gênesis, onde se narra a história da luta de Jacó com Deus. Deus não vence Jacob na luta (embora este não soubesse que lutava com Ele), e Jacob é rebatizado com o nome de Ismael, que significa "aquele que luta com Deus."

${ }^{46}$ GIDE. Oscar Wilde. In memoriam, p. 476-477.

${ }^{47}$ GIDE. Oscar Wilde. In memoriam, p. 476-477. 